\title{
Clinical significance of serum claudin-1 and claudin-7 levels in patients with colorectal cancer
}

\author{
MEHMET KARABULUT ${ }^{1}$, HALIL ALIS $^{1}$, KORAY BAS $^{1}$, SENEM KARABULUT $^{2}$, CIGDEM USUL AFSAR $^{3}$, \\ HILAL OGUZ ${ }^{4}$, MERAL GUNALDI $^{5}$, CEVHER AKARSU $^{1}$, OSMAN KONES $^{1}$ and NURI FARUK AYKAN ${ }^{2}$ \\ ${ }^{1}$ Clinic of General Surgery, Istanbul Bakırköy Dr Sadi Konuk Education and Research Hospital, 34156 Istanbul; \\ ${ }^{2}$ Department of Medical Oncology, Institute of Oncology, Istanbul University, 34093 Istanbul; ${ }^{3}$ Department of \\ Medical Oncology, Istanbul Education and Research Hospital, 34098 Istanbul; ${ }^{4}$ Department of Basic \\ Oncology, Institute of Oncology, Istanbul University, 34390 Istanbul; ${ }^{5}$ Clinic of Medical Oncology, \\ Istanbul Bakirköy Dr Sadi Konuk Education and Research Hospital, 34156 Istanbul, Turkey
}

Received May 5, 2015; Accepted August 18, 2015

DOI: $10.3892 / \operatorname{mco} .2015 .626$

\begin{abstract}
The present study aimed to investigate the serum levels and clinical relevance of claudin (CLDN) 1 and CLDN7 in patients with colorectal cancer (CRC). A total of 140 patients with a pathologically confirmed diagnosis of CRC were enrolled in this study. The serum levels of CLDN1 and CLDN7 were determined using the solid-phase sandwich ELISA method. A total of 40 healthy age- and gender-matched controls were included in the analysis. The median age of the patients was 60 years (range, 24-84 years). The localization of the tumor in the majority of the patients was the colon $(n=81$, $58 \%$ ). Of the 55 metastatic patients who received palliative chemotheraphy, $31 \%$ were chemotherapy-responsive. The baseline median serum CLDN1 and CLDN7 levels were significantly lower in non-metastatic and metastatic patients compared with those in healthy controls (CLND1, $\mathrm{P}=0.008$ and 0.002; and CLND7, $\mathrm{P}=0.002$ and 0.002 , respectively). Moreover, known clinical variables, including poor performance status and high carcinoembryonic antigen (CEA) levels were found to be associated with lower serum CLDN1 concentrations for all patients $(\mathrm{P}=0.03$ and $\mathrm{P}=0.03$, respectively). High $\mathrm{T}$ stage and high CEA levels were found to be correlated with lower serum CLDN7 concentrations for all patients $(\mathrm{P}=0.04$ and 0.03 , respectively). A correlation was identified between CLDN1 and CLDN7 levels in non-metastatic and metastatic CRC patients (both P-values <0.001). Our study results did not reveal any statistical significance for serum CLDN1 or CLND7 concentrations regarding progression-free and overall survival rate. Therefore, reduced serum levels of CLDN1 and
\end{abstract}

Correspondence to: Dr Mehmet Karabulut, Clinic of General Surgery, Istanbul Bakırköy Dr Sadi Konuk Education and Research Hospital, Zuhuratbaba Street, 11 Tevfik Sağlam Road, 34156 Istanbul, Turkey

E-mail:mehmet-mac@hotmail.com

Key words: claudin-1, claudin-7, serum, low levels, colorectal cancer
CLND7 may be useful markers in the differential diagnosis of CRC.

\section{Introduction}

Colorectal cancer (CRC) is one of the leading causes of cancer-related mortality worldwide (1). According to the National Cancer Institute (Surveillance, Epidemiology and End Results Program), the Centers for Disease Control and Prevention (National Program of Cancer Registries), the North American Association of Central Cancer Registries and the National Center for Health Statistics, 132,700 new cases of large bowel cancer are diagnosed annually in the USA, of which 93,090 are colon and the remainder rectal cancers. A total of $\sim 49,700$ Americans succumb to CRC annually, accounting for $\sim 8 \%$ of all cancer deaths (2). The mortality rates from CRC have declined since the 1980s in the USA and in certain western countries. However, the mortality rates continue to increase in less developed countries with limited resources for healthcare, particularly in Central and South America and Eastern Europe (3-5). Even with the current diagnostic tools and screening programs, due to the high incidence rates of $\mathrm{CRC}$, particularly in underdeveloped countries, there remains the need to develop cost-effective and convenient early diagnostic strategies, such as molecular biomarkers, to reduce the mortality rates of this disease.

Paracellular tight junctions regulate paracellular permeability and play a critical role in apical cell-to-cell adhesion and epithelial cell polarity (6). Claudins (CLDNs) are important proteins in this structure. There are currently $\geq 24$ known members of the CLDN family $(7,8)$. CLDNs were first named by Japanese researchers Tsukita and Furuse in 1998. The name 'claudin' is derived from the Latin word claudere, which means 'to close', suggesting the barrier role of these proteins (9).

As regards the molecular biology of cancer, it has been demonstrated that CLDNs are abnormally regulated and, therefore, are promising molecular targets for cancer diagnosis, prognosis and therapy. CLDN1 and CLDN7 are major building blocks of paracellular adhesion molecules. The significance of these tight junction proteins for local invasion by neoplastic 
cells and development of metastasis has been confirmed by numerous studies over the last decade and their decreased expression in CRC appears to significantly affect cell proliferation, motility, invasion and antitumor immune response (10).

In this study, we aimed to investigate the association between clinicopathological findings and the serum levels of CLDN1 and CLDN7 in CRC. To the best of our knowledge, this is the first study using ELISA, which is a more practical and cost-effective technique compared with immunohistochemistry (IHC) or polymerase chain reaction (PCR) analysis for measuring these CLDNs in CRC.

\section{Materials and methods}

Study design and eligibility criteria. Serum samples were obtained from 140 consecutive patients with CRC who were referred to the Institute of Oncology of the Istanbul University and the Istanbul Bakirköy Dr Sadi Konuk Training and Research Hospital (Istanbul, Turkey) between 2011 and 2014. All the patients were staged using the seventh edition of the American Joint Committee on Cancer tumor-node-metastasis system by radiological and pathological criteria (11).

All the patients were treated using a multidisciplinary approach. Patients with colon cancer who had undergone surgery including segmental colon resection were treated with adjuvant chemotherapy (CTx) according to their stage. Patients with rectal cancer who received neoadjuvant radiochemotherapy (RCTx) or radiotherapy (RT) had undergone low anterior resection or abdominoperineal resection. Certain patients had undergone palliative surgery and stage IV patients received palliative CTx, with or without targeted therapy (bevacizumab or cetuximab). The pretreatment evaluation included detailed clinical history and physical examination with a series of biochemistry tests and complete blood cell counts. Selection for treatment required an Eastern Cooperative Oncology Group performance status (PS) score of $0-2$, and adequate bone marrow (absolute neutrophil count $>1,500 / \mu 1$ and platelet count $>100,000 / \mu 1)$, cardiac, renal and hepatic functions. The patients were treated with various CTx regimens, including single-agent or combination therapy. Regimens of single-agent or combination CTx were selected according to the PS of the patients and extent of the disease. The patients received one of the following treatment regimens: Simplified LV5FU2 (leucovorin $400 \mathrm{mg} / \mathrm{m}^{2}$, followed by 5 -fluorouracil as a $400 \mathrm{mg} / \mathrm{m}^{2}$ bolus and a $2,400 \mathrm{mg} / \mathrm{m}^{2}$ infusion over $46 \mathrm{~h}$ every 2 weeks), capecitabine $\left(1,000 \mathrm{mg} / \mathrm{m}^{2} /\right.$ b.i.d., p.o. for 14 days of each 21-day cycle), modified FOLFOX regimen (simplified LV5FU2 regimen plus oxaliplatin $85 \mathrm{mg} / \mathrm{m}^{2}$ every 2 weeks), FOLFIRI (simplified LV5FU2 regimen plus irinotecan $180 \mathrm{mg} / \mathrm{m}^{2}$ every 2 weeks), XELOX (capecitabine $1,000 \mathrm{mg} / \mathrm{m}^{2} /$ b.i.d., p.o. for 14 days plus oxaliplatin $130 \mathrm{mg} / \mathrm{m}^{2}$ every 3 weeks), and XELIRI (capecitabine 1,000 mg/m²/b.i.d., p.o. for 14 days plus irinotecan $240 \mathrm{mg} / \mathrm{m}^{2}$ every 3 weeks). Bevacizumab was administered at a dose schedule of either $5 \mathrm{mg} / \mathrm{kg}$ every 2 weeks, or $7.5 \mathrm{mg} / \mathrm{kg}$ every 3 weeks. Cetuximab $500 \mathrm{mg} / \mathrm{m}^{2}$ was administered intravenously every 2 weeks.

All the patients had undergone pretreatment imaging of primary tumors with magnetic resonance imaging (MRI) or computed tomography $(\mathrm{CT})$. For patients with evaluable imaging studies prior to and following treatment, radiological response was recorded according to the Response Evaluation Criteria in Solid Tumors, version 1.1, and classified as complete response (CR), partial response (PR), stable disease (SD), or progressive disease (PD) (12). The tumor response after 2 months of CTx was used for statistical analysis. Follow-up for metastatic disease included clinical and laboratory tests, and CT or MRI, depending on which imaging method was used at baseline, and performed at 8-week intervals during CTx or every 12 weeks for patients receiving no anticancer treatment. Patients with either CR or PR were classified as responders, whereas patients with $\mathrm{SD}$ or $\mathrm{PD}$ were considered as non-responders.

This study was approved by the Institutional Review Board of the Institute of Oncology, Istanbul University. Baseline demographic, clinical and laboratory data including age, gender, PS, tumor marker levels, KRAS mutation status and treatment details, were retrospectively collected for all patients using uniform database templates to ensure consistent data collection. The comorbidities of the patients mainly included cardiac and metabolic diseases.

The control group consisted of 40 age- and gender-matched healthy controls were age and gender matched to the patients. with no previous history of malignancy or autoimmune disorders. Blood samples were obtained from CRC patients at first admission, 1 month after surgery and 2 weeks prior to adjuvant or palliative CTx. Blood samples from healthy controls were collected into dry tubes and serum was separated from cellular elements by centrifugation (at $1,788 \mathrm{x}$ g) within $30 \mathrm{~min}$ after the blood samples were stored at $-80^{\circ} \mathrm{C}$ until analysis. All the samples were collected following approval by the Institutional Review Board and provision of written informed consent by all the participants.

Measurement of serum CLDN1 and CLDN7 levels. A double-antibody sandwich ELISA was used to determine the levels of CLDN1 and CLDN7 (cat. nos. YHB0737Hu and YHB0720Hu, respectively; YH Biosearch Laboratory, Shanghai, China) in the samples. in the samples. The undiluted serum samples and standards were added to the wells, which were pre-coated with human CLDN1 and CLDN7 monoclonal antibody against human CLDN1 and CLDN7. Then, the antiCLDN1 and anti-CLDN7 antibodies labeled with biotin and the streptavidin-horseradish peroxidase conjugate were added to the wells to form an immune complex. After incubation at $37^{\circ} \mathrm{C}$ for $1 \mathrm{~h}$, the unbound material was washed away with the diluted washing concentrate provided by the kit. Chromogen TMB (3,3', 5,5;-tetramethylbenzidine) solution was added as the substrate for HRP and incubated at $37^{\circ} \mathrm{C}$ for $10 \mathrm{~min}$ (protected from light) for the conversion of the colorless solution to a blue solution, the intensity of which was proportional to the amount of CLDN1 and CLDN7 in the sample. Under the effect of the acidic stop solution, the color turned to yellow and the colored reaction product was measured using an automated ELISA microplate reader (ChroMate ${ }^{\circledR}$ 4300; Awareness Technology, Inc., Palm City, FL, USA) at $450 \mathrm{~nm}$. The results were expressed as $\mathrm{ng} / \mathrm{ml}$.

Statistical analysis. IBM SPSS software for Windows, version 21.0 (IBM Corp., Armonk, NY, USA) was used for data analysis. Continuous variables were categorized using 
Table I. Patient and disease characteristics.

\begin{tabular}{ll}
\hline Variables & $n$ \\
\hline
\end{tabular}

No. of patients
Age, years
Median (range)
Gender

Male/female

Performance status ${ }^{\mathrm{a}}$

$0 / 1 / 2 / 3$

Smoking ${ }^{\mathrm{a}}$

Yes/no

Alcohol intake ${ }^{\mathrm{a}}$

Yes/no

Comorbidity $^{\mathrm{a}}$

Yes/no

$60(24-84)$

$96 / 44$

$68 / 61 / 7 / 1$

$61 / 66$

26/99

$56 / 79$

Obstruction

Yes/no

$17 / 123$

Type of surgery

Colectomy

56

36

13

11

Palliative

Pathological T stage ${ }^{\mathrm{b}}$

$0 / 1 / 2 / 3 / 4$

Pathological N stage ${ }^{\mathrm{b}}$

$0 / 1 / 2$

$9 / 2 / 12 / 45 / 10$

$42 / 18 / 14$

Pathological stage

2/3/4

$17 / 64 / 59$

Tumor location

Colon/rectum

Response to $\mathrm{CTx}^{\mathrm{c}}$

$\mathrm{CR} / \mathrm{PR} / \mathrm{SD} / \mathrm{PD} /$ unknown

Metastasis $^{\mathrm{d}}$

Yes/no

Histology

Adenocarcinoma/mucinous $\mathrm{Ca}$

Grade of differentiation ${ }^{\mathrm{b}}$

$1 / 2 / 3$

Lymphatic invasion $^{\mathrm{b}}$

Yes/no

$30 / 18$

Vascular invasion ${ }^{\mathrm{b}}$

Yes/no

$16 / 30$

Perineural invasion ${ }^{\mathrm{b}}$

Yes/no

Regression score ${ }^{\mathrm{e}}$

$1 / 2 / 3 / 4$

$1 / 12 / 4 / 8$

KRAS mutation status ${ }^{c}$

Mutant/wild-type

Lactate dehydrogenase $^{\text {a }}$ (cut-off, 450 IU/1)

Normal/high
Table I. Continued.

Variables n n

Albumin $^{\text {a }}$ (cut-off, 4 gr/dl)

Normal/low

$54 / 58$

Carcinoembryonic antigen ${ }^{\text {a }}$ (cut-off, $5 \mathrm{ng} / \mathrm{ml}$ )

Normal/high

$78 / 17$

Carbohydrate antigen 19-9 (cut-off, $38 \mathrm{U} / \mathrm{ml}$ )

Normal/high

$81 / 28$

aPatients with unknown data regarding the variables were not included in the analysis. 'In 81 non-metastatic patients (patients with unknown data concerning the variables are not included in the analysis). 'In 59 patients with metastatic CRC. ${ }^{\mathrm{d}}$ Stage II or III. ${ }^{\mathrm{e}}$ In 37 patients with rectal cancer who received neoadjuvant treatment. CR, complete response; $\mathrm{PR}$, partial response; $\mathrm{SD}$, stable disease; $\mathrm{PD}$, progressive disease; CRC, colorectal cancer; $\mathrm{Ca}$, carcinoma.

median values as the cut-off point. The Chi-square test or one-way analysis of variance were used for group comparison of categorical variables, and the Mann-Whitney U test or Kruskall-Wallis test were used for comparison of continuous variables. The Spearman's rank order correlation was used for correlation analysis. Overall survival (OS) was calculated from the date of first admission to disease-related death or date of last contact with the patient or any family member. Progression-free survival (PFS) was calculated from the date of admission to the date of first radiographic evidence of disease progression, with/without elevated serum tumor marker levels. The Kaplan-Meier method was used for the estimation of survival distribution and differences in PFS and OS were assessed by the log-rank statistics. All the statistical tests were two-sided and $\mathrm{P}<0.05$ was considered to indicate a statistically significant difference.

\section{Results}

Patient characteristics. A total of 140 patients who were pathologically diagnosed with CRC between May, 2011 and August, 2014, were included in the present study. The baseline demographic and histopathological/laboratory characteristics of the patients are summarized in Table I. The median age of the patients was 60 years (range, 24-84 years), with a male predominance $(n=96,69 \%)$. A total of 43 patients had family history of cancer, including 12 lung cancers and 14 CRCs. The tumor localization was in the rectum in $59(42 \%)$ and in the colon in $81(58 \%)$ patients (right colon, $n=17$; hepatic flexure, $n=5$; transverse colon, $\mathrm{n}=5$; descending colon, $\mathrm{n}=13$; splenic flexure, $\mathrm{n}=1$; sigmoid colon, $\mathrm{n}=37$; multiple synchronous colon tumors, $\mathrm{n}=3$; and rectosigmoid junction tumors, $n=6$ ). The most frequent metastatic sites were the liver $(n=40,67.8 \%)$ and the peritoneum $(n=17,28.8 \%)$. The rate of synchronous $(n=34)$ and metachronous metastasis $(n=25)$ was 57.6 and $42.4 \%$, respectively. Of the 37 patients with rectal cancer who received neoadjuvant treatment, 28 received fluoropyrimidine-based RCTx, whereas 9 received short-course RT. A total of 71 patients who were treated with adjuvant CTx received one of the following 
Table II. Comparison of serum marker levels in CRC patients and healthy controls.

\begin{tabular}{lccc}
\hline Subjects & $\mathrm{n}$ & $\begin{array}{c}\text { CLDN1 level (ng/ml), } \\
\text { median (range) }\end{array}$ & $\begin{array}{c}\text { CLDN7 level (ng/ml), } \\
\text { median (range) }\end{array}$ \\
\hline All patients & 140 & $8.4(1.8-48.8)$ & $11.57(0.13-87.35)$ \\
Controls & 40 & $9.5(6.2-48.9)$ & $26.64(8.92-87.17)$ \\
P-value & & $0.005^{\mathrm{b}}$ & $<0.001^{\mathrm{b}}$ \\
Non-metastatic patients & 81 & $8.5(3.3-43.1)$ & $12.05(2.14-87.35)$ \\
Controls & 40 & $9.5(6.2-48.9)$ & $26.64(8.92-87.17)$ \\
P-value & & $0.008^{\mathrm{b}}$ & $0.002^{\mathrm{b}}$ \\
Metastatic patients & 59 & $8.1(1.8-48.8)$ & $11.45(0.13-87.15)$ \\
Controls & 40 & $9.5(6.2-48.9)$ & $26.64(8.92-87.17)$ \\
P-value & & $0.02^{\mathrm{b}}$ & $0.002^{\mathrm{b}}$ \\
\hline
\end{tabular}

aStage II or III. 'Statistically significant $(\mathrm{P}<0.05)$. CRC, colorectal cancer; CLDN, claudin.

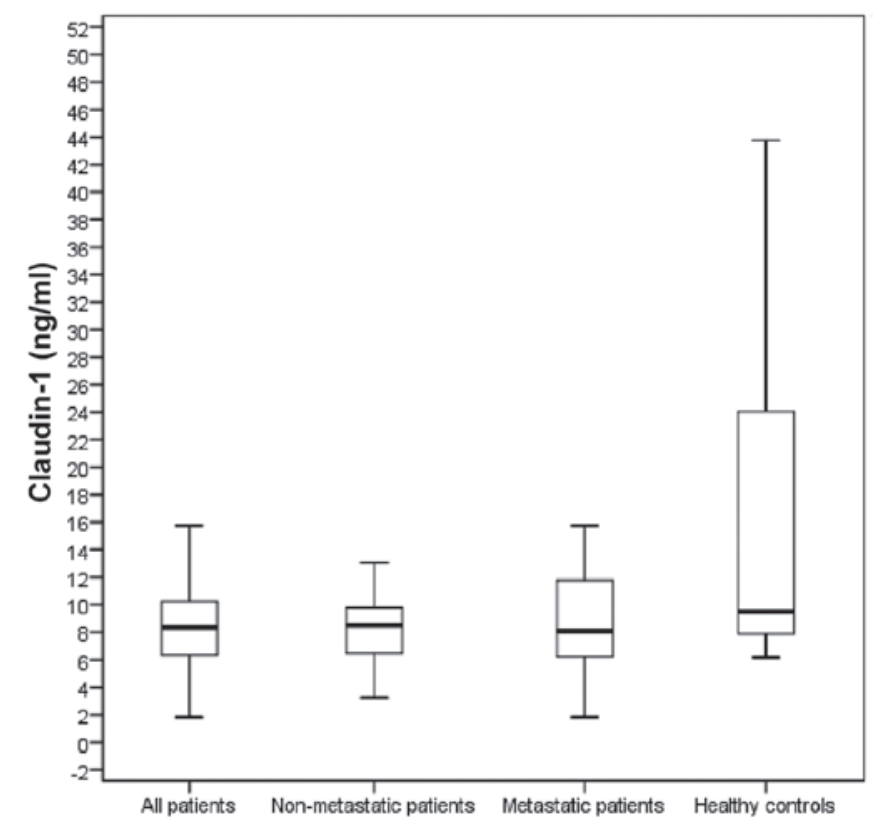

Figure 1. Values of serum CLDN1 assays in all, non-metastatic (stage II/III) and metastatic CRC patients and controls $(\mathrm{P}=0.005,0.008$ and 0.02 , respectively). CLDN, claudin; CRC, colorectal cancer.

treatment regimens: Simplified LV5FU2/capecitabine $(n=14)$, mFOLFOX regimen $(n=26)$, and XELOX $(n=31)$. Palliative CTx included oxaliplatin-based or irinotecan-based combination CTx regimens and single-agent fluoropyrimidine in 24, 22 , and 9 patients, respectively. Bevacizumab was administered to 36 patients, whereas 15 patients received cetuximab as the targeted agent. Response to CTx was observed in $31 \%$ of the 55 metastatic patients who received palliative CTX.

Comparison of CLDN1 and CLDN7 levels between CRC patients and controls. The levels of serum CLDN1 and CLDN7 of all CRC patients and healthy controls are presented in Table II. The baseline serum CLDN1 levels were significantly lower in all the patients compared with those in the control group (8.4 vs. $9.5 \mathrm{ng} / \mathrm{ml}$, respectively; $\mathrm{P}=0.005)$. The

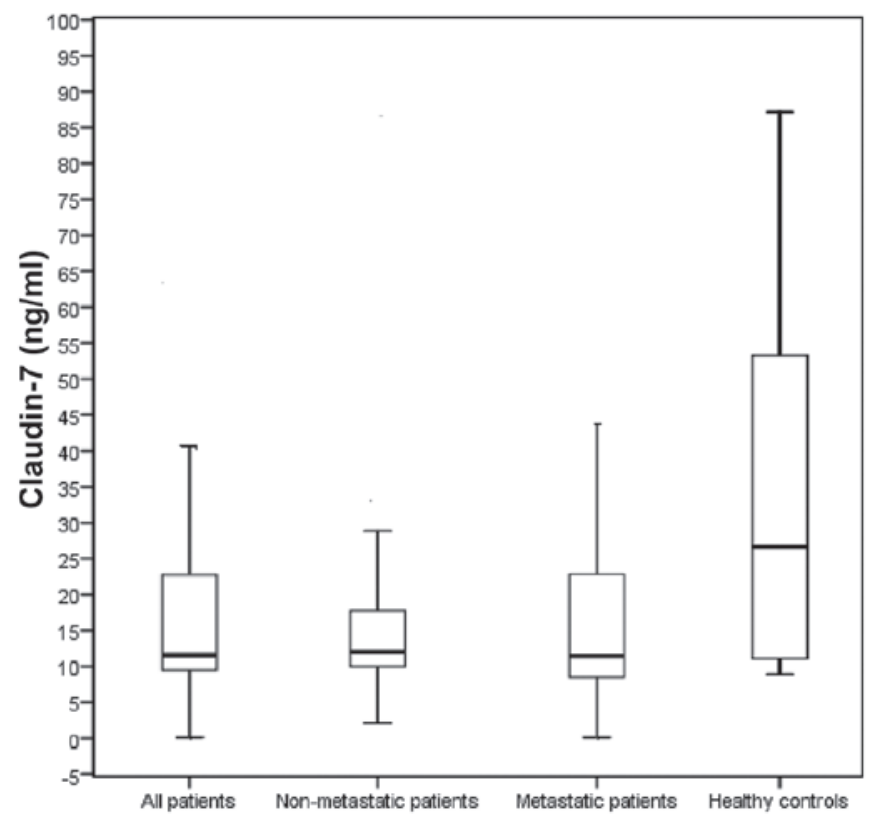

Figure 2. Values of serum CLDN7 assays in all, non-metastatic (stage II/III) and metastatic CRC patients and controls $(\mathrm{P}<0.001, \mathrm{P}=0.002$ and $\mathrm{P}=0.002$, respectively). CLDN, claudin; CRC, colorectal cancer.

baseline serum CLDN7 levels of all the patients were also significantly lower compared with those in the control group (11.57 vs. $26.64 \mathrm{ng} / \mathrm{ml}$, respectively; $\mathrm{P}<0.001)$. The baseline serum CLDN1 levels in non-metastatic (stage II/III; $8.5 \mathrm{ng} / \mathrm{ml}$ ) and metastatic patients $(8.1 \mathrm{ng} / \mathrm{ml})$ were significantly lower compared with those in the control group $(\mathrm{P}=0.008$ and 0.02 , respectively; Fig. 1). The baseline serum CLDN7 levels in non-metastatic $(12.05 \mathrm{ng} / \mathrm{ml})$ as well as those in metastatic patients $(11.45 \mathrm{ng} / \mathrm{ml})$ were also significantly lower compared with those in the control group (both P-values $=0.002$; Fig. 2).

Correlation between serum levels of CLDN1 and CLDN7 and clinicopathological factors. The correlation between the serum levels of CLDN1 and CLDN7 and clinicopathological factors is shown in Tables III and IV. Poor PS and high 


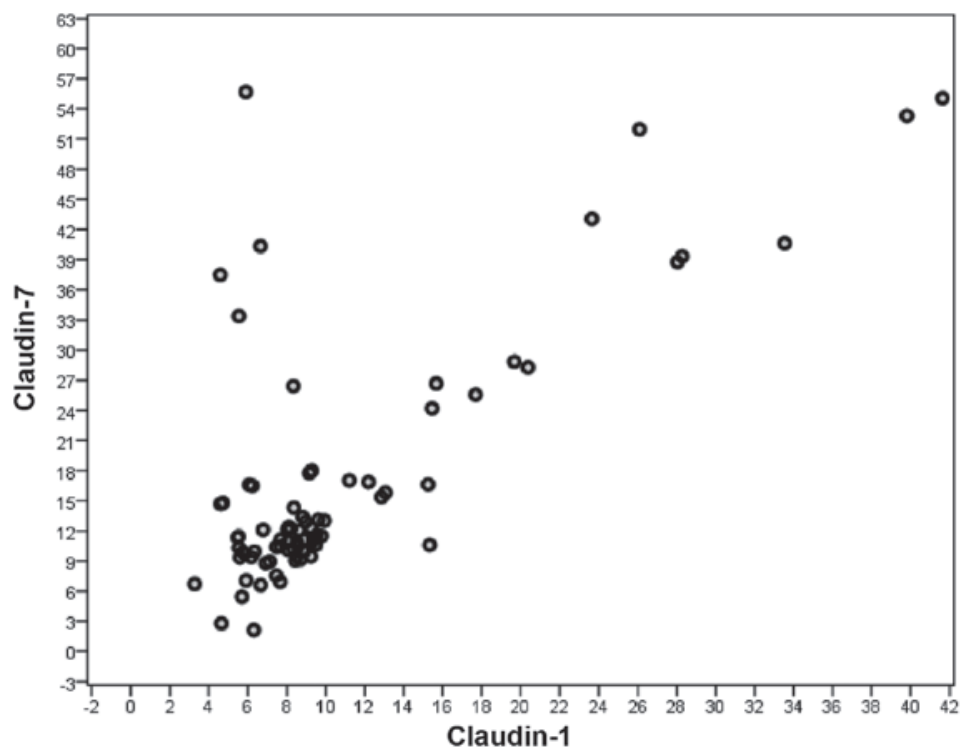

Figure 3. Correlation between serum CLDN1 and CLDN7 levels in non-metastatic (stage II and III) CRC patients ( $r s=0.632, n=81, \mathrm{P}<0.001$ ), (Spearman's correlation). CLDN, claudin; CRC, colorectal cancer.

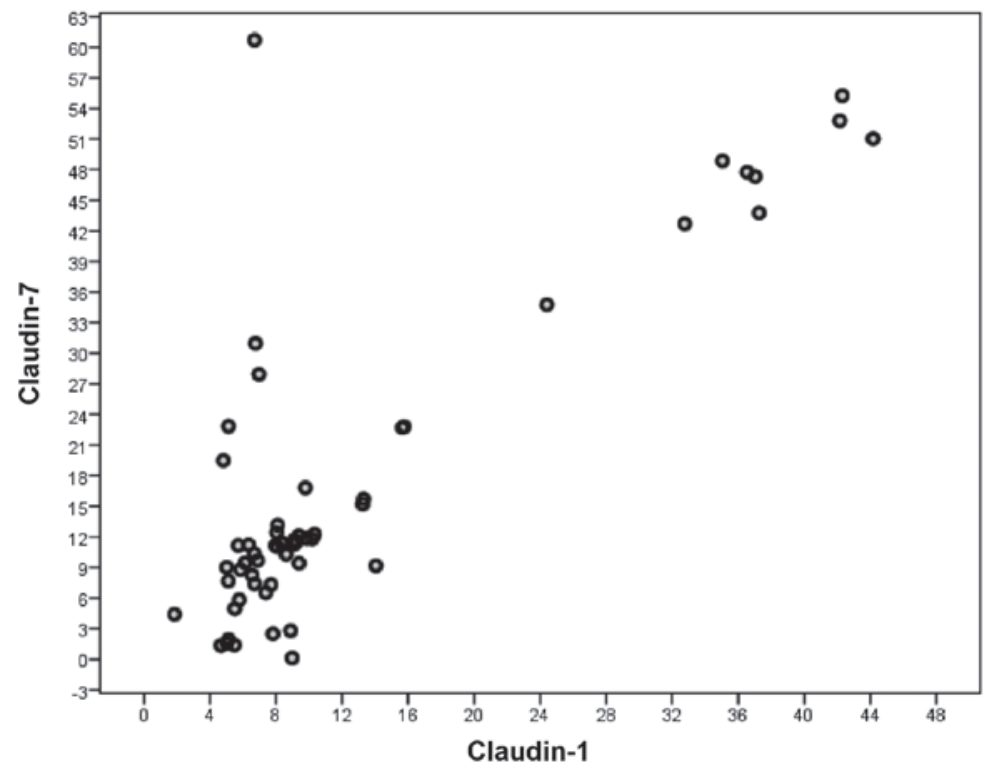

Figure 4. Correlation between serum CLDN1 and CLDN7 levels in metastatic CRC patients ( $r s=0.706, n=59, P<0.001$ ), (Spearman's correlation). CLDN, claudin; CRC, colorectal cancer.

carcinoembryonic antigen (CEA) levels were found to be associated with lower serum CLDN1 concentrations for all patients (both P-values $=0.03$ ). High tumor stage and high CEA levels were found to be correlated with lower serum CLDN7 concentrations for all patients $(\mathrm{P}=0.04$ and 0.02 , respectively).

A significant correlation was observed between serum CLDN1 and CLDN7 levels in all CRC patients ( $r s=0.672, n=140$, $\mathrm{P}<0.001)$. Such a correlation was not observed between serum CLDN1 and CLDN7 levels in non-metastatic CRC patients ( $r s=0.632, n=81, P<0.001$ ), but it was observed between serum CLDN1 and CLDN7 levels in metastatic CRC patients ( $\mathrm{rs}=0.706$, $\mathrm{n}=59, \mathrm{P}<0.001)$ (Spearman's correlation) (Figs. 3 and 4).

Folllow-up. The median follow-up time was 14 months (range, 1-34 months). A total of 43 patients (31\%) experienced disease progression, whereas 31 of the remaining patients (22\%) succumbed to the disease. The median PFS and OS of the entire group were $7.3 \pm 1.0$ months (95\% CI: 5-9 months) and 26.9 \pm 1.1 months (95\% CI: 25-29 months), respectively. The 1-year PFS rate was $26.2 \%$ (95\% CI: 12.9-39.5) and the 1- and 2-year OS rates were $82.7 \%$ (95\% CI: 76.2-89.2) and $70.1 \%$ (95\% CI: 58.8-81.2), respectively. There was a significant association between certain clinicopathological variables, including presence of metastasis $(\mathrm{P}=0.05)$, no surgical resection $(\mathrm{P}=0.01), \mathrm{CTX}$-unresponsiveness $(\mathrm{P}=0.001)$, high serum $\mathrm{CEA}(\mathrm{P}=0.04)$ and carbohydrate antigen $(\mathrm{CA})$ 19-9levels $(\mathrm{P}=0.03)$ and poorer PFS (Tables V and VI). Among the clinicopathological variables evaluated, rectal localization $(\mathrm{P}=0.03)$, presence of metastasis $(\mathrm{P}<0.001)$, vascular invasion $(\mathrm{P}=0.02)$, perineural invasion $(\mathrm{P}=0.03)$, poor differentiation $(\mathrm{P}=0.02)$, low $\mathrm{PS}$ 
Table III. Results of comparisons between the serum assays and various demographic and disease characteristics.

\begin{tabular}{|c|c|c|c|c|c|}
\hline Variables & $\mathrm{n}$ & $\begin{array}{l}\text { CLDN1 level (ng/ml), } \\
\text { median (range) }\end{array}$ & P-value & $\begin{array}{c}\text { CLDN7 level (ng/ml), } \\
\text { median (range) }\end{array}$ & P-value \\
\hline Age (years) & & & 0.75 & & 0.85 \\
\hline$<50$ & 22 & $8.3(4.5-42.2)$ & & $11.02(1.36-87.15)$ & \\
\hline$\geq 50$ & 118 & $8.4(1.8-48.8)$ & & $11.67(0.13-87.35)$ & \\
\hline Gender & & & 0.62 & & 0.26 \\
\hline Male & 96 & $8.5(1.8-48.8)$ & & $11.99(0.13-87.35)$ & \\
\hline Female & 44 & $8.1(4.7-43.1)$ & & $10.99(1.36-60.70)$ & \\
\hline PS & & & $0.03^{\mathrm{b}}$ & & 0.57 \\
\hline 0 & 68 & $8.9(3.3-44.2)$ & & $12.18(1.92-55.07)$ & \\
\hline $1-3$ & 69 & $7.8(1.8-48.8)$ & & $11.45(0.13-87.35)$ & \\
\hline Smoking & & & 0.79 & & 0.39 \\
\hline Yes & 61 & $8.4(1.8-48.8)$ & & $12.24(0.13-87.35)$ & \\
\hline No & 66 & $8.6(3.3-42.3)$ & & $11.10(1.39-55.25)$ & \\
\hline Alcohol intake & & & 0.63 & & 0.49 \\
\hline Yes & 26 & $8.4(3.3-37.0)$ & & $11.44(0.13-47.32)$ & \\
\hline No & 99 & $8.5(1.8-48.8)$ & & $11.81(1.39-87.35)$ & \\
\hline Comorbidity & & & 0.56 & & 0.62 \\
\hline Yes & 56 & $8.5(4.6-48.8)$ & & $11.39(0.13-65.93)$ & \\
\hline No & 79 & $8.3(1.8-42.3)$ & & $11.81(1.36-87.35)$ & \\
\hline Obstruction & & & 0.25 & & 0.12 \\
\hline Yes & 17 & $6.9(5.0-33.5)$ & & $9.68(2.49-87.35)$ & \\
\hline No & 123 & $8.4(1.8-48.8)$ & & $12.05(0.13-87.15)$ & \\
\hline Surgery & & & 0.72 & & 0.91 \\
\hline Yes & 116 & $8.4(3.3-44.2)$ & & $11.48(1.36-87.35)$ & \\
\hline No & 24 & $8.2(1.8-48.8)$ & & $11.84(0.13-65.93)$ & \\
\hline T stage & & & 0.59 & & $0.04^{\mathrm{a}}$ \\
\hline $0-2$ & 23 & $8.6(3.3-20.4)$ & & $12.27(2.14-87.35)$ & \\
\hline $3-4$ & 55 & $8.5(4.6-43.1)$ & & $10.99(2.80-28.27)$ & \\
\hline $\mathrm{N}$ stage & & & 0.32 & & 0.55 \\
\hline 0 & 42 & $8.4(3.3-39.8)$ & & $11.54(2.80-55.69)$ & \\
\hline $1-2$ & 32 & $8.8(4.6-43.1)$ & & $12.20(2.14-87.35)$ & \\
\hline Metastasis & & & 0.84 & & 0.44 \\
\hline Yes & 59 & $8.1(1.8-48.8)$ & & $11.45(0.13-87.15)$ & \\
\hline $\mathrm{No}^{\mathrm{a}}$ & 81 & $8.5(3.3-43.1)$ & & $12.05(2.14-87.35)$ & \\
\hline Response to CTx & & & 0.88 & & 0.72 \\
\hline Yes (CR + PR) & 17 & $7.7(1.8-42.3)$ & & $9.68(2.80-55.25)$ & \\
\hline No (SD + PD) & 34 & $8.3(4.7-44.2)$ & & $11.41(0.13-60.70)$ & \\
\hline Tumor location & & & 0.32 & & 0.33 \\
\hline Colon & 81 & $8.4(3.3-48.8)$ & & $12.05(0.13-87.35)$ & \\
\hline Rectum & 59 & $8.3(1.8-39.8)$ & & $11.48(1.92-60.70)$ & \\
\hline
\end{tabular}

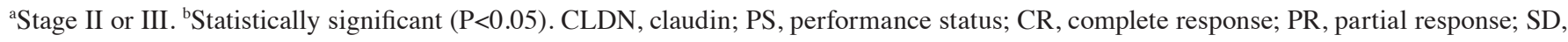
stable disease; PD, progressive disease; CTx, chemotherapy.

$(\mathrm{P}=0.02)$, no surgical resection $(\mathrm{P}<0.001), \mathrm{CTx}$-unresponsiveness $(\mathrm{P}=0.002)$, high serum levels of lactate dehydrogenase $(\mathrm{LDH})$ $(\mathrm{P}=0.02)$, CEA $(\mathrm{P}<0.001)$ and CA 19-9 $(\mathrm{P}<0.001)$, and low serum levels of albumin $(\mathrm{P}=0.02)$, were found to be correlated with poorer OS (Tables VII and VIII). However, serum CLDN1 and CLDN7 levels exerted no significantly adverse effect on PFS or OS (CLDN1, P=0.93 and 0.48, respectively; and CLND7, $\mathrm{P}=0.43$ and 0.18 , respectively) (Tables VI and VIII and Figs. 5-8). Moreover, the serum CLDN1 or CLDN7 levels of metastatic and non-metastatic patients exerted no significant adverse effect 
Table IV. Results of comparisons between the serum assays and various histopathological characteristics and laboratory parameters.

\begin{tabular}{|c|c|c|c|c|c|}
\hline Variables & $\mathrm{n}$ & $\begin{array}{l}\text { CLDN1 level (ng/ml), } \\
\text { median (range) }\end{array}$ & P-value & $\begin{array}{l}\text { CLDN7 level (ng/ml), } \\
\text { median (range) }\end{array}$ & P-value \\
\hline Histology & & & 0.12 & & 0.70 \\
\hline Adenocarcinoma & 129 & $8.3(1.8-48.8)$ & & $11.62(0.13-87.35)$ & \\
\hline Mucinous carcinoma & 11 & $9.2(5.6-42.2)$ & & $11.48(8.95-52.80)$ & \\
\hline Grade of differentiation & & & 0.27 & & 0.51 \\
\hline High & 8 & $8.9(8.3-19.7)$ & & $12.15(9.06-28.83)$ & \\
\hline Intermediate & 56 & $8.1(1.8-43.1)$ & & $11.09(1.36-87.35)$ & \\
\hline Poor & 6 & $9.2(5.7-17.7)$ & & $14.38(9.90-25.56)$ & \\
\hline Lymphatic invasion & & & 0.54 & & 0.82 \\
\hline Yes & 30 & $8.1(4.6-43.1)$ & & $12.20(6.62-87.35)$ & \\
\hline No & 18 & $8.8(3.3-41.6)$ & & $12.18(6.72-55.69)$ & \\
\hline Vascular invasion & & & 0.71 & & 0.85 \\
\hline Yes & 16 & $8.2(4.7-23.7$ & & $12.58(6.62-87.35)$ & \\
\hline No & 30 & $8.8(3.3-43.1)$ & & $12.26(6.72-59.48)$ & \\
\hline Perineural invasion & & & 0.64 & & 0.85 \\
\hline Yes & 18 & $8.7(4.6-43.1)$ & & $13.86(6.62-59.48)$ & \\
\hline No & 28 & $8.4(3.3-41.6)$ & & $12.12(6.72-87.35)$ & \\
\hline Regression score & & & 0.27 & & 0.35 \\
\hline $1-2$ & 13 & $8.9(5.5-39.8)$ & & $11.34(2.14-53.31)$ & \\
\hline $3-4$ & 12 & $8.6(4.7-12.2)$ & & $10.65(2.80-18.01)$ & \\
\hline KRAS mutation status & & & 0.99 & & 0.70 \\
\hline Mutant & 24 & $8.3(5.1-44.2)$ & & $11.18(0.13-59.48)$ & \\
\hline Wild-type & 28 & $8.3(1.8-48.8)$ & & $11.84(1.36-65.93)$ & \\
\hline LDH level & & & 0.11 & & 0.40 \\
\hline Normal & 97 & $8.6(1.8-44.2)$ & & $11.72(0.13-87.35)$ & \\
\hline High & 16 & $9.3(6.7-48.8)$ & & $16.26(2.49-65.93)$ & \\
\hline Albumin level & & & 0.54 & & 0.83 \\
\hline Normal & 54 & $8.4(1.8-44.2)$ & & $11.39(2.80-60.70)$ & \\
\hline Low & 58 & $8.9(3.3-48.8)$ & & $12.12(0.13-87.35)$ & \\
\hline CEA level & & & $0.03^{\mathrm{a}}$ & & $0.02^{\mathrm{a}}$ \\
\hline Normal & 78 & $8.7(3.3-43.1)$ & & $12.11(1.36-87.35)$ & \\
\hline High & 17 & $6.8(1.8-44.2)$ & & $10.36(1.39-51.03)$ & \\
\hline CA 19-9 level & & & 0.52 & & 0.21 \\
\hline Normal & 81 & $8.5(1.8-42.2)$ & & $11.48(1.36-87.35)$ & \\
\hline High & 28 & $7.9(5.0-44.2)$ & & $11.24(0.13-60.70)$ & \\
\hline
\end{tabular}

${ }^{\text {aS }}$ tatistically significant $(\mathrm{P}<0.05)$. CEA, carcinoembryonic antigen; CA, carbohydrate antigen; LDL, lactate dehydrogenase; $\mathrm{CLDN}$, claudin.

on PFS or OS (CLND1: $\mathrm{P}=0.75$ and 0.09 , and $\mathrm{P}=0.77$ and 0.07 , respectively; and CLND7: $\mathrm{P}=0.56$ and 0.08 , and $\mathrm{P}=0.07$ and 0.82 , respectively) (Tables VI and VIII).

\section{Discussion}

It is commonly accepted that the risk of developing CRC is affected by environmental as well as genetic factors (13). Although certain risk factors and etiological agents have been indicated in different studies over several years (14-16), there is a need to fully elucidate the molecular background of CRC, in order to develop effective biomolecular tools to decrease the mortality rate of this disease through early diagnosis. Thus far, different molecular substances and detection techniques have been investigated for this purpose, such as tight juction proteins.

Tight junction proteins regulate cellular permeability and play a crucial role in cell-to-cell adhesion and epithelial polarity. CLDNs are major integral membrane proteins of tight junctions. CLDN loss of expression or overexpression varies in different cancer types. In hepatocellular carcinoma and renal cell carcinoma, the expression of CLDN4 and CLDN5 is lost, whereas CLDN3 and CLDN4 overexpression has been detected in pancreatic ductal adenocarcinoma and cancers of the 
Table V. Univariate analyses of progression-free survival according to patient and disease characteristics.

\begin{tabular}{|c|c|c|c|c|}
\hline Variables & No. of events/total no. & $\begin{array}{l}\text { Median survival, } \\
\text { months }( \pm \mathrm{SE})\end{array}$ & $\begin{array}{c}\text { 1-year survival rate, } \\
\%( \pm \mathrm{SE})\end{array}$ & P-value \\
\hline All patients & $43 / 140$ & $7.3(1.0)$ & $26.2(6.8)$ & \\
\hline Age, years & & & & 0.45 \\
\hline$<50$ & $6 / 22$ & $8.3(2.2)$ & NR & \\
\hline$\geq 50$ & $37 / 118$ & $7.2(1.1)$ & $25.0(7.2)$ & \\
\hline Gender & & & & 0.46 \\
\hline Male & $29 / 96$ & $7.5(1.1)$ & $28.6(8.5)$ & \\
\hline Female & $14 / 44$ & $7.1(2.1)$ & NR & \\
\hline PS & & & & 0.30 \\
\hline 0 & $11 / 68$ & $8.7(2.1)$ & NR & \\
\hline $1-3$ & $32 / 69$ & $6.9(1.2)$ & $24.1(7.9)$ & \\
\hline Obstruction & & & & 0.43 \\
\hline Yes & $6 / 17$ & $6.3(1.9)$ & NR & \\
\hline No & $33 / 123$ & $7.4(1.1)$ & $24.2(7.5)$ & \\
\hline Surgery & & & & $0.01^{\mathrm{b}}$ \\
\hline Yes & $32 / 116$ & $8.3(1.2)$ & $31.3(8.2)$ & \\
\hline No & $11 / 24$ & $4.2(1.3)$ & NR & \\
\hline T stage & & & & 0.85 \\
\hline $0-2$ & $2 / 23$ & $11.0(3.2)$ & NR & \\
\hline $3-4$ & $8 / 55$ & $10.0(6.0)$ & NR & \\
\hline $\mathrm{N}$ stage & & & & 0.20 \\
\hline 0 & $4 / 42$ & $6.5(3.2)$ & NR & \\
\hline $1-2$ & $6 / 32$ & $13.7(3.7)$ & NR & \\
\hline Metastasis & & & & $0.05^{\mathrm{b}}$ \\
\hline Yes & $33 / 59$ & $6.3(0.9)$ & $21.9(7.3)$ & \\
\hline $\mathrm{No}^{\mathrm{a}}$ & $10 / 81$ & $10.8(2.7)$ & NR & \\
\hline Response to CTx & & & & $0.001^{\mathrm{b}}$ \\
\hline Yes (CR + PR) & $4 / 17$ & $14.8(2.3)$ & NR & \\
\hline No (SD + PD) & $27 / 34$ & $4.1(0.6)$ & NR & \\
\hline Tumor location & & & & 0.18 \\
\hline Colon & $19 / 81$ & $8.3(1.4)$ & $33.3(11.1)$ & \\
\hline Rectum & $24 / 59$ & $6.6(1.3)$ & $20.8(8.3)$ & \\
\hline Histology & & & & 0.79 \\
\hline Adenocarcinoma & $37 / 129$ & $8.2(2.6)$ & $24.3(7.1)$ & \\
\hline Mucinous carcinoma & $5 / 11$ & $7.2(1.1)$ & NR & \\
\hline Grade of differentiation & & & & 0.79 \\
\hline High & $1 / 8$ & NR & $9.0(0.0)$ & \\
\hline Intermediate & $13 / 56$ & NR & $7.5(2.2)$ & \\
\hline Poor & $2 / 6$ & NR & $5.5(2.5)$ & \\
\hline Regression score & & & & 0.90 \\
\hline $1-2$ & $2 / 12$ & $9.5(6.5)$ & NR & \\
\hline $3-4$ & $0 / 13$ & $4.0(0.0)$ & NR & \\
\hline KRAS mutation status & & & & 0.14 \\
\hline Mutant & $14 / 24$ & $4.9(1.2)$ & NR & \\
\hline Wild-type & $14 / 28$ & $7.6(1.7)$ & NR & \\
\hline
\end{tabular}

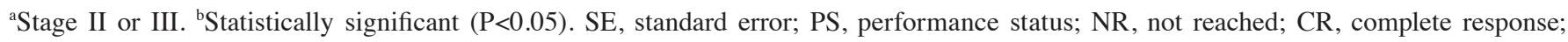
$\mathrm{PR}$, partial response; $\mathrm{SD}$, stable disease; $\mathrm{PD}$, progressive disease; CTx, chemotherapy. 
Table VI. Univariate analyses of progression-free survival according to laboratory parameters.

\begin{tabular}{|c|c|c|c|c|}
\hline Variables & No. of events/total no. & $\begin{array}{l}\text { Median survival, } \\
\text { months }( \pm \mathrm{SE})\end{array}$ & $\begin{array}{c}\text { 1-year survival rate, } \\
\%( \pm \mathrm{SE})\end{array}$ & P-value \\
\hline LDH level & & & & 0.14 \\
\hline Normal & $27 / 97$ & $7.1(1.1)$ & $25.9(8.4)$ & \\
\hline High & $5 / 16$ & $12.6(5.0)$ & NR & \\
\hline Albumin level & & & & 0.57 \\
\hline Normal & $12 / 54$ & $7.6(1.6)$ & $26.3(10.7)$ & \\
\hline Low & $19 / 58$ & $8.9(2.1)$ & $41.7(14.2)$ & \\
\hline CEA level & & & & $0.04^{\mathrm{b}}$ \\
\hline Normal & $16 / 78$ & $8.9(1.5)$ & $43.8(12.4)$ & \\
\hline High & $9 / 17$ & $5.2(2.1)$ & NR & \\
\hline CA 19-9 level & & & & $0.03^{\mathrm{b}}$ \\
\hline Normal & $18 / 81$ & $9.1(1.3)$ & $38.9(11.5)$ & \\
\hline High & $19 / 28$ & $6.5(1.7)$ & $21.1(9.4)$ & \\
\hline CLDN1 of all patients & & & & 0.93 \\
\hline$<$ median & $23 / 43$ & $7.5(1.4)$ & $26.1(9.2)$ & \\
\hline$>$ median & $20 / 43$ & $7.1(1.4)$ & $26.3(10.1)$ & \\
\hline CLDN1 of non-metastatic patients ${ }^{a}$ & & & & 0.77 \\
\hline$<$ median & $5 / 41$ & $11.8(4.8)$ & NR & \\
\hline$>$ median & $5 / 40$ & $9.8(3.1)$ & NR & \\
\hline CLDN1 of metastatic patients & & & & 0.75 \\
\hline$<$ median & $16 / 30$ & $6.3(1.2)$ & $25.0(10.8)$ & \\
\hline$>$ median & $17 / 29$ & $6.2(1.4)$ & $18.8(9.8)$ & \\
\hline CLDN7 of all patients & & & & 0.43 \\
\hline$<$ median & $22 / 43$ & $6.6(1.2)$ & $22.7(8.9)$ & \\
\hline$>$ median & $21 / 43$ & $8.2(1.6)$ & $30.0(10.2)$ & \\
\hline CLDN7 of non-metastatic patients ${ }^{\mathrm{a}}$ & & & & 0.07 \\
\hline$<$ median & $4 / 40$ & $14.0(3.5)$ & NR & \\
\hline$>$ median & $6 / 41$ & $6.0(3.3)$ & NR & \\
\hline CLDN7 of metastatic patients & & & & 0.56 \\
\hline$<$ median & $16 / 30$ & $5.5(1.2)$ & NR & \\
\hline$>$ median & $17 / 29$ & $6.9(1.4)$ & NR & \\
\hline
\end{tabular}

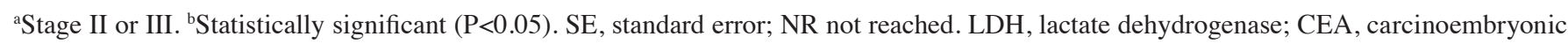
antigen; CA, carbohydrate antigen; CLDN, claudin.

prostate, uterus, ovary and breast. Particularly CLDN1, CLDN4 and CLDN7, which are referred to as the 'impermeability CLDNs' are important building blocks of paracellular adhesion molecules; it was demonstrated that their decreased expression in CRC appears to exert major effects on cell proliferation, motility, invasion and antitumor immune response (17-19).

Previous studies have investigated the role of CLDNs on different cancer types using IHC or PCR $(20,21)$. To the best of our knowledge, this is the first study to compare CLDN1 and CLDN7 serum levels between healthy individuals and CRC patients using ELISA.

It was previously suggested that loss of CLDN expression plays a role in carcinogenesis through repression of tight junctions and cell proliferation, motility and invasion (22). Resnick et al (23) demonstrated that weak CLDN1 expression was associated with high grade and poor survival, and it was an independent predictor of recurrence. Ersoz et al (24) reported that CLDN1 expression was significantly decreased in lymph node-positive cases.

For different types of cancer, a number of studies have compared CLDN7 expression between malignant and normal tissues. It was previously reported that CLDN7 expression is lower in squamous cell carcinoma of the oesophagus (25), head and neck (26), breast $(27,28)$ and nasopharyngeal cancer (29); however, it appears to be upregulated in ovarian (30) and gastric cancer (31). Nakayama et al (32) also reported lower expression of CLDN7 in $\sim 80 \%$ of invasive CRCs compared with non-neoplastic tissues.

Süren et al (17) recently demonstrated a significant association between loss of CLDN1 and CLDN7 expression, as 
Table VII. Univariate analyses of overall survival according to patient and disease characteristics.

\begin{tabular}{|c|c|c|c|c|}
\hline Variables & No. of events/total no. & $\begin{array}{l}\text { Median survival, } \\
\text { months }( \pm \mathrm{SE})\end{array}$ & $\begin{array}{c}\text { 1-year survival rate, } \\
\%( \pm \mathrm{SE})\end{array}$ & P-value \\
\hline All patients & $31 / 140$ & $26.9(1.1)$ & $82.7(3.3)$ & \\
\hline $\begin{array}{l}\text { Age, years } \\
<50 \\
\geq 50\end{array}$ & $\begin{array}{c}4 / 22 \\
27 / 118\end{array}$ & $\begin{array}{l}22.1(1.4) \\
26.8(1.2)\end{array}$ & $\begin{array}{l}90.9(6.1) \\
81.1(3.8)\end{array}$ & 0.30 \\
\hline $\begin{array}{l}\text { Gender } \\
\text { Male } \\
\text { Female }\end{array}$ & $\begin{array}{l}20 / 96 \\
11 / 44\end{array}$ & $\begin{array}{l}26.3(1.3) \\
26.7(1.9)\end{array}$ & $\begin{array}{l}83.3(4.0) \\
81.5(5.9)\end{array}$ & 0.76 \\
\hline $\begin{array}{l}\text { PS } \\
0 \\
1-3\end{array}$ & $\begin{array}{c}9 / 68 \\
22 / 69\end{array}$ & $\begin{array}{l}25.4(1.7) \\
23.1(0.9)\end{array}$ & $\begin{array}{l}87.5(4.2) \\
77.3(5.2)\end{array}$ & $0.02^{\mathrm{b}}$ \\
\hline $\begin{array}{l}\text { Obstruction } \\
\text { Yes } \\
\text { No }\end{array}$ & $\begin{array}{c}5 / 17 \\
23 / 123\end{array}$ & $\begin{array}{l}20.7(2.0) \\
27.5(1.3)\end{array}$ & $\begin{array}{l}81.1(9.9) \\
83.1(3.6)\end{array}$ & 0.50 \\
\hline $\begin{array}{l}\text { Surgery } \\
\text { Yes } \\
\text { No }\end{array}$ & $\begin{array}{c}20 / 116 \\
11 / 24\end{array}$ & $\begin{array}{l}28.6(1.1) \\
13.3(2.0)\end{array}$ & $\begin{array}{l}88.0(3.1) \\
56.9(10.4)\end{array}$ & $<0.001^{\mathrm{b}}$ \\
\hline $\begin{array}{l}\text { T stage } \\
0-2 \\
3-4\end{array}$ & $\begin{array}{l}0 / 23 \\
3 / 55\end{array}$ & $\begin{array}{l}\text { NR } \\
\text { NR }\end{array}$ & $\begin{array}{r}100.0(0.0) \\
98.2(1.8)\end{array}$ & 0.28 \\
\hline $\begin{array}{l}\text { N stage } \\
0 \\
1-2\end{array}$ & $\begin{array}{l}1 / 42 \\
2 / 32\end{array}$ & $\begin{array}{l}32.3(0.7) \\
32.3(1.2)\end{array}$ & $\begin{array}{r}97.6(2.4) \\
100.0(0.0)\end{array}$ & 0.43 \\
\hline $\begin{array}{l}\text { Metastasis } \\
\text { Yes } \\
\text { No }^{\mathrm{a}}\end{array}$ & $\begin{array}{c}27 / 59 \\
4 / 81\end{array}$ & $\begin{array}{l}15.9(1.4) \\
32.5(0.7)\end{array}$ & $\begin{array}{l}61.1(6.8) \\
97.5(1.7)\end{array}$ & $<0.001^{\mathrm{b}}$ \\
\hline $\begin{array}{l}\text { Response to CTx } \\
\text { Yes (CR+PR) } \\
\text { No (SD+PD) }\end{array}$ & $\begin{array}{c}2 / 17 \\
19 / 34\end{array}$ & $\begin{array}{l}23.6(1.6) \\
11.9(1.4)\end{array}$ & $\begin{array}{l}93.3(6.4) \\
47.6(9.4)\end{array}$ & $0.002^{\mathrm{b}}$ \\
\hline $\begin{array}{l}\text { Tumor location } \\
\text { Colon } \\
\text { Rectum }\end{array}$ & $\begin{array}{c}8 / 81 \\
23 / 59\end{array}$ & $\begin{array}{l}29.2(1.2) \\
24.7(1.6)\end{array}$ & $\begin{array}{l}91.0(3.8) \\
76.6(4.9)\end{array}$ & $0.03^{\mathrm{b}}$ \\
\hline $\begin{array}{l}\text { Histology } \\
\text { Adenocarcinoma } \\
\text { Mucinous carcinoma }\end{array}$ & $\begin{array}{c}28 / 129 \\
3 / 11\end{array}$ & $\begin{array}{l}27.7(1.1) \\
18.5(2.7)\end{array}$ & $\begin{array}{l}84.4(3.3) \\
70.7(14.3)\end{array}$ & 0.48 \\
\hline $\begin{array}{l}\text { Grade of differentiation } \\
\text { High } \\
\text { Intermediate } \\
\text { Poor }\end{array}$ & $\begin{array}{c}0 / 8 \\
6 / 56 \\
3 / 6\end{array}$ & $\begin{array}{l}\text { NR } \\
\text { NR } \\
\text { NR }\end{array}$ & $\begin{array}{c}100.0(0.0) \\
90.7(4.0) \\
66.7(19.2)\end{array}$ & $0.02^{\mathrm{b}}$ \\
\hline $\begin{array}{l}\text { Lymphatic invasion } \\
\text { Yes } \\
\text { No }\end{array}$ & $\begin{array}{l}3 / 30 \\
0 / 18\end{array}$ & $\begin{array}{l}\text { NR } \\
\text { NR }\end{array}$ & $\begin{array}{r}96.6(3.4) \\
100.0(0.0)\end{array}$ & 0.25 \\
\hline $\begin{array}{l}\text { Vascular invasion } \\
\text { Yes } \\
\text { No }\end{array}$ & $\begin{array}{l}3 / 16 \\
0 / 30\end{array}$ & $\begin{array}{l}\text { NR } \\
\text { NR }\end{array}$ & $\begin{array}{r}93.3(6.4) \\
100.0(0.0)\end{array}$ & $0.02^{\mathrm{b}}$ \\
\hline $\begin{array}{l}\text { Perineural invasion } \\
\text { Yes } \\
\text { No }\end{array}$ & $\begin{array}{l}3 / 18 \\
0 / 28\end{array}$ & $\begin{array}{l}\text { NR } \\
\text { NR }\end{array}$ & $\begin{array}{r}94.1(5.7) \\
100.0(0.0)\end{array}$ & $0.03^{\mathrm{b}}$ \\
\hline $\begin{array}{l}\text { Regression score } \\
1-2 \\
3-4\end{array}$ & $\begin{array}{l}1 / 12 \\
0 / 13\end{array}$ & $\begin{array}{l}\text { NR } \\
\text { NR }\end{array}$ & $\begin{array}{r}91.7(8.0) \\
100.0(0.0)\end{array}$ & 0.30 \\
\hline $\begin{array}{l}\text { KRAS mutation status } \\
\text { Mutant } \\
\text { Wild-type }\end{array}$ & $\begin{array}{c}13 / 24 \\
8 / 28\end{array}$ & $\begin{array}{l}15.1(2.0) \\
18.2(2.1)\end{array}$ & $\begin{array}{l}52.6(10.3) \\
75.8(9.7)\end{array}$ & 0.25 \\
\hline
\end{tabular}

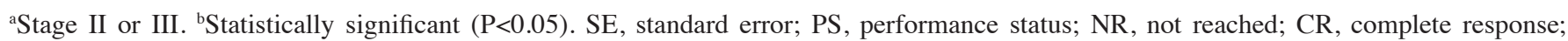
$\mathrm{PR}$, partial response; $\mathrm{SD}$, stable disease; $\mathrm{PD}$, progressive disease. 
Table VIII. Univariate analyses of overall survival according to laboratory parameters.

\begin{tabular}{|c|c|c|c|c|}
\hline Variables & No. of events/total no. & $\begin{array}{l}\text { Median survival, } \\
\text { months }( \pm \mathrm{SE})\end{array}$ & $\begin{array}{c}\text { 1-year survival rate, } \\
\%( \pm \mathrm{SE})\end{array}$ & P-value \\
\hline LDH level & & & & $0.02^{\mathrm{b}}$ \\
\hline Normal & $21 / 97$ & $21.5(0.9)$ & $84.6(3.8)$ & \\
\hline High & $7 / 16$ & $20.5(3.8)$ & $62.5(12.1)$ & \\
\hline Albumin level & & & & $0.02^{\mathrm{b}}$ \\
\hline Normal & $7 / 54$ & $23.2(1.0)$ & $89.8(4.3)$ & \\
\hline Low & $20 / 58$ & $23.4(1.9)$ & $73.7(5.8)$ & \\
\hline CEA level & & & & $<0.001^{\mathrm{b}}$ \\
\hline Normal & $7 / 78$ & $24.4(0.6)$ & $95.7(2.5)$ & \\
\hline High & $6 / 17$ & $17.9(2.6)$ & $68.0(12.2)$ & \\
\hline CA 19-9 level & & & & $<0.001^{\mathrm{b}}$ \\
\hline Normal & $10 / 81$ & $23.8(0.7)$ & $93.4(2.9)$ & \\
\hline High & $13 / 28$ & $20.0(2.8)$ & $61.5(9.7)$ & \\
\hline CLDN1 of all patients & & & & 0.48 \\
\hline$<$ median & $15 / 71$ & $27.3(1.5)$ & $85.1(4.4)$ & \\
\hline$>$ median & $16 / 69$ & $20.9(1.1)$ & $80.2(5.0)$ & \\
\hline CLDN1 of non-metastatic patients ${ }^{a}$ & & & & 0.07 \\
\hline$<$ median & $0 / 40$ & NR & $100.0(0.0)$ & \\
\hline$>$ median & $4 / 41$ & NR & $95.1(3.4)$ & \\
\hline CLDN1 of metastatic patients & & & & 0.09 \\
\hline$<$ median & $11 / 30$ & $17.6(1.7)$ & $70.3(9.0)$ & \\
\hline$>$ median & $16 / 29$ & $13.8(2.0)$ & $51.7(9.9)$ & \\
\hline CLDN7 of all patients & & & & 0.18 \\
\hline$<$ median & $13 / 70$ & $22.2(1.0)$ & $86.1(4.3)$ & \\
\hline$>$ median & $18 / 70$ & $25.6(1.7)$ & $79.3(4.9)$ & \\
\hline CLDN7 of non-metastatic patients ${ }^{a}$ & & & & 0.82 \\
\hline$<$ median & $2 / 40$ & $24.2(0.6)$ & $97.6(2.4)$ & \\
\hline$>$ median & $2 / 41$ & $32.5(1.1)$ & $97.5(2.5)$ & \\
\hline CLDN7 of metastatic patients & & & & 0.08 \\
\hline$<$ median & $11 / 30$ & $12.4(1.8)$ & $73.7(8.7)$ & \\
\hline$>$ median & $16 / 29$ & $16.8(1.4)$ & $69.4(9.6)$ & \\
\hline
\end{tabular}

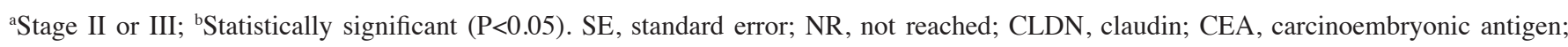
$\mathrm{CA}$, carbohydrate antigen; LDH, lactate dehydrogenase.

determined by IHC, and invasion depth, lymph node status, disease stage, grade, perineural invasion and lymphovascular invasion in $70 \mathrm{CRC}$ patients; they observed mild loss (score 1) of CLDN1 expression in 43 (61.4\%) and moderate-to-marked loss (score 2 and 3 ) in 27 patients (38.6\%). For CLDN7, there was no loss of expression (score 0) in 16 (22.9\%), mild loss (score 1) in $30(42.9 \%)$ and moderate-to-marked loss (score 3 ) in 24 patients $(34.2 \%)$ of the same group. Similarly, in the present study, we observed a negative correlation between CRC and the serum levels of CLDN1 and CLDN7 as determined by ELISA. The baseline serum CLDN1 levels were significantly lower in all CRC patients compared with those in the control group. Similar to CLDN1, the baseline serum CLDN7 levels of all patients were significantly lower compared with those in the control group. Our results also suggest that the decrease in the levels of CLDN1 and CLDN7 reflect the stage of the disease. The baseline serum CLDN1 levels of non-metastatic (stage II/III) and metastatic patients were significantly lower compared with those in the control group. The baseline serum CLDN7 levels of non-metastatic and metastatic patients were also significantly lower compared with those in the control group.

In another study using IHC, Nakagawa et al (33) demonstrated that, among $119 \mathrm{CRC}$ patients, the postoperative OS rate was significantly higher in patients exhibiting high expression of CLDN1 compared with the low-expression group for a median follow-up of 3.9 years. The disease-free survival rate following curative surgery was also higher in the high-expression compared with that in the low-expression group. Their univariate analysis revealed that grade 


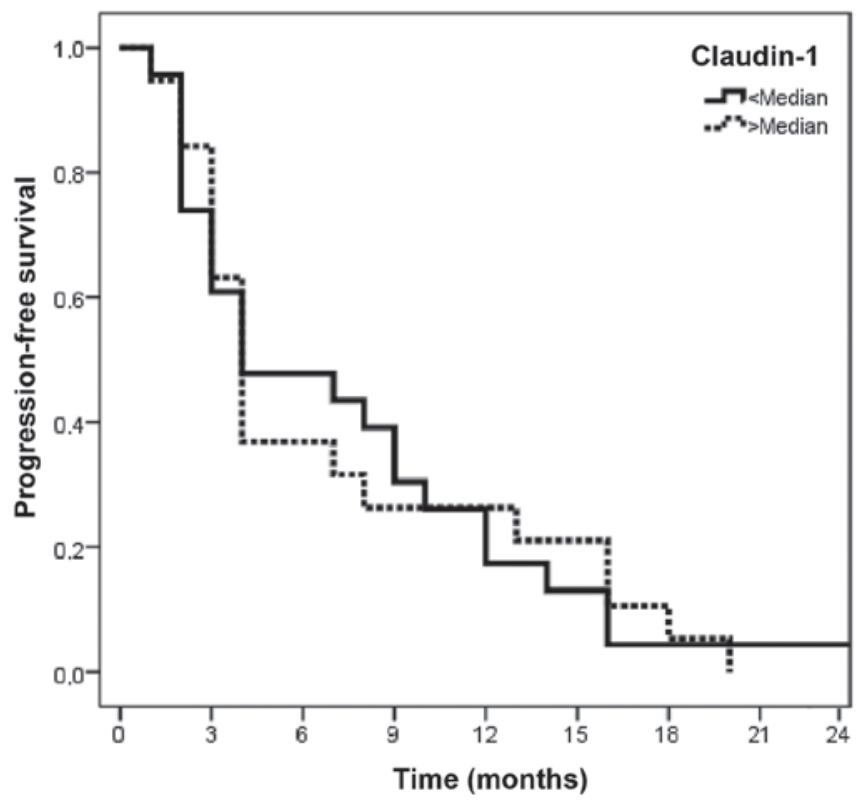

Figure 5. Progression-free survival curves in CRC patients according to serum CLDN1 levels $(\mathrm{P}=0.93)$. CLDN, claudin; $C R C$, colorectal cancer.

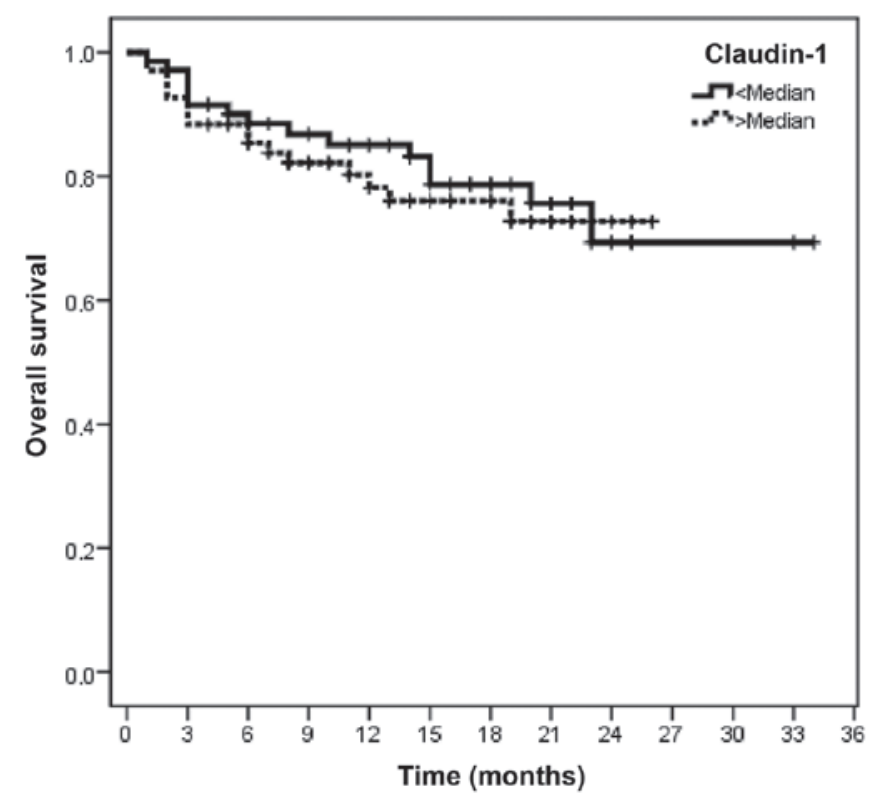

Figure 6. Overall survival curves in CRC patients according to serum CLDN1 levels $(\mathrm{P}=0.48)$. CLDN, claudin; $\mathrm{CRC}$, colorectal cancer.

of differentiation, morphological type, tumor size, tumor invasion, lymph node metastasis, lymphatic invasion, venous invasion, metastasis and CLDN1 expression were significantly correlated with OS. In addition, the multivariate regression analysis indicated that high expression of CLDN1 and metastasis were independent predictors of OS. They also observed that CRC patients with high expression of CLDN1 had a better prognosis in terms of disease-free survival compared with the low-expression group, which is consistent with our findings. In our analysis, we investigated the correlation between the serum levels of CLDN1 and CLDN7 and clinicopathological factors. Poor PS and high CEA levels were found to be associated with lower

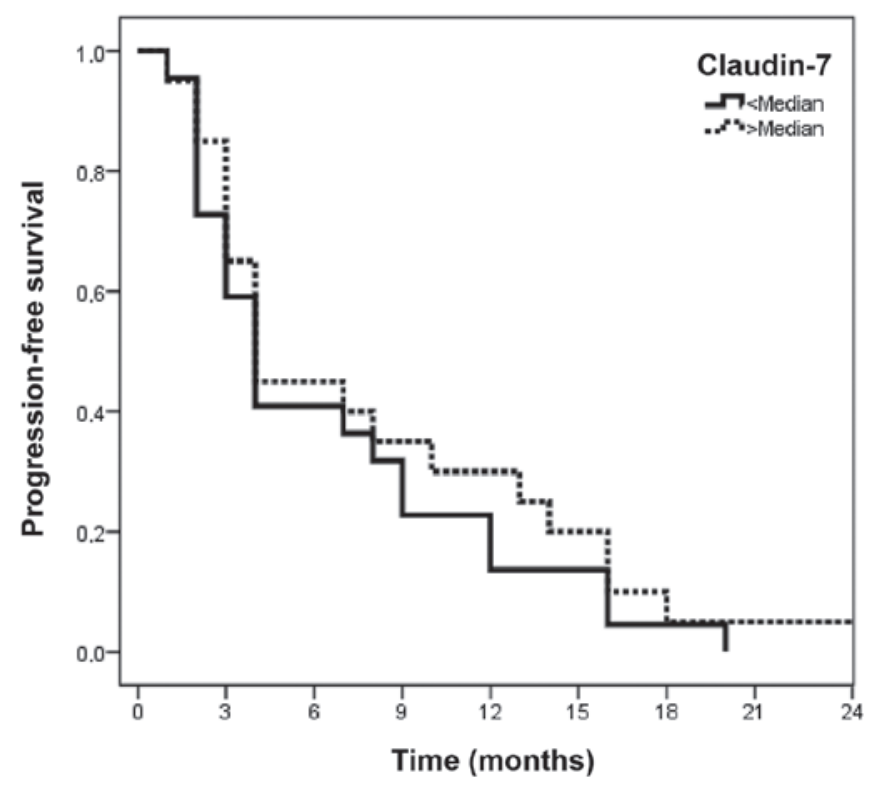

Figure 7. Progression-free survival curves in CRC patients according to serum CLDN7 levels $(\mathrm{P}=0.43)$. CLDN, claudin; $\mathrm{CRC}$, colorectal cancer.

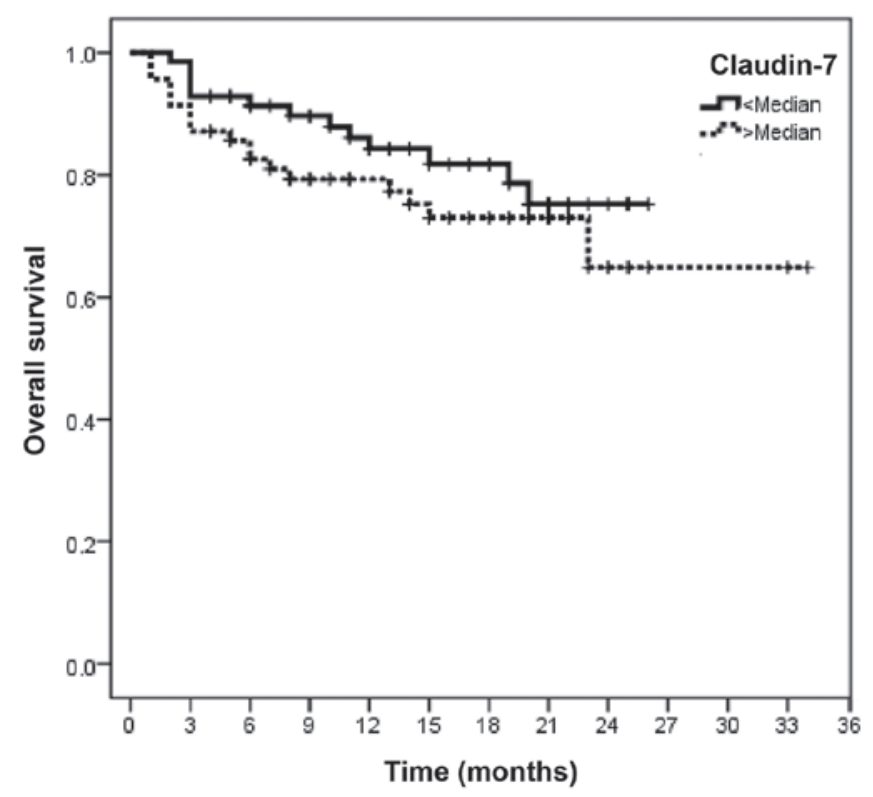

Figure 8. Overall survival curves in CRC patients according to serum CLDN7 levels $(\mathrm{P}=0.18)$. $\mathrm{CLDN}$, claudin; $\mathrm{CRC}$, colorectal cancer.

serum CLDN1 concentrations for all patients. High T stage and high CEA levels were also found to be correlated with lower serum CLDN7 concentrations for all patients. Such a correlation was not observed between serum CLDN1 and CLDN7 levels in non-metastatic CRC patients, but it was observed between serum CLDN1 and CLDN7 levels in metastatic CRC patients. Our median follow-up time was 14 months (range, 1-34 months). The median PFS and OS of the entire group were 7.3 and 26.9 months, respectively. We observed a significant association between other clinicopathological variables, including presence of metastasis, no surgical resection, CTx-unresponsiveness, and high serum levels of CEA and CA19-9, and poorer PFS. Among the 
clinicopathological variables evaluated, localization in the rectum, presence of metastasis, vascular invasion, perineural invasion, poor differentiation, low PS, no surgical resection and CTX-unresponsiveness were found to be correlated with poorer OS, as expected. However, the serum CLDN1 and CLDN7 levels exerted no significantly adverse effect on PFS or OS over this limited follow-up time.

In conclusion, CLDN1 and CLDN7 are important barrier proteins of the human cell structure and their decreased expression in CRC appears to play a central role in tumor cell motility and invasion. Therefore, reduced serum levels of CLDN1 and CLND7, as determined by ELISA, may be a useful tool in the differential diagnosis of CRC.

\section{References}

1. Siegel R, Naishadham D and Jemal A: Cancer statistics, 2013 CA Cancer J Clin 63: 11-30, 2013.

2. Siegel RL, Miller KD and Jemal A: Cancer statistics, 2015. CA Cancer J Clin 65: 5-29, 2015.

3. Center MM, Jemal A, Smith RA and Ward E: Worldwide variations in colorectal cancer. CA Cancer J Clin 59: 366-378, 2009.

4. Jemal A, Simard EP, Dorell C, Noone AM, Markowitz LE, Kohler B, Eheman C, Saraiya M, Bandi P, Saslow D, et al: Annual Report to the Nation on the Status of Cancer, 1975-2009, featuring the burden and trends in human papillomavirus (HPV)-associated cancers and HPV vaccination coverage levels. J Natl Cancer Inst 105: 175-201, 2013.

5. Kohler BA, Ward E, McCarthy BJ, Schymura MJ, Ries LA, Eheman C, Jemal A, Anderson RN, Ajani UA and Edwards BK Annual Report to the Nation on the Status of Cancer, 1975-2007, featuring tumors of the brain and other nervous system. J Nat Cancer Inst 103: 714-736, 2011.

6. Singh AB, Sharma A and Dhawan P: Claudin family of proteins and cancer: An overview. J Oncol 2010: 541957, 2010.

7. Furuse M, Fujita K, Hiiragi T, Fujimoto K and Tsukita S: Claudin-1 and -2: Novel integral membrane proteins localizing at tight junctions with no sequence similarity to occludin. J Cell Biol 141: 1539-1550, 1998.

8. Rahner C, Mitic LL and Anderson JM: Heterogeneity in expression and subcellular localization of claudins $2,3,4$, and 5 in the rat liver, pancreas, and gut. Gastroenterology 120: 411-422, 2001.

9. Tsukita S, Furuse M and Itoh M: Multifunctional strands in tight junctions. Nat Rev Mol Cell Biol 2: 285-293, 2001.

10. Kyuno D, Yamaguchi H, Ito T, Kono T, Kimura Y, Imamura M, Konno T, Hirata K, Sawada N and Kojima T: Targeting tight junctions during epithelial to mesenchymal transition in human pancreatic cancer. World J Gastroenterol 20: 10813-10824, 2014.

11. Edge SB and Compton CC: The American Joint Committee on Cancer: the 7th edition of the AJCC cancer staging manual and the future of TNM. Ann Surg Oncol 17: 1471-1474, 2010.

12. Eisenhauer EA, Therasse P, Bogaerts J, et al: New response evaluation criteria in solid tumours: revised RECIST guideline (version 1.1). Eur J Cancer 45: 228-247, 2009.

13. Chan AT and Giovannucci EL: Primary prevention of colorectal cancer. Gastroenterology. 138: 2029-2043.e10, 2010.

14. Moon BS, Jeong WJ, Park J, Kim TI, Min S and Choi KY: Role of oncogenic K-Ras in cancer stem cell activation by aberrant Wnt//3-catenin signaling. J Natl Cancer Inst 106: djt373, 2014.

15. Wei EK, Giovannucci E, Wu K, Rosner B, Fuchs CS, Willett WC and Colditz GA: Comparison of risk factors for colon and rectal cancer. Int J Cancer 108: 433-442, 2004.

16. Fearon ER and Vogelstein B: A genetic model for colorectal tumorigenesis. Cell 61: 759-767, 1990.
17. Süren D, Yıldırım M, Kaya V, Alikanoğlu AS, Bülbüller N, Y1ld1z M and Sezer C: Loss of tight junction proteins (claudin 1, 4 and 7) correlates with aggressive behavior in colorectal carcinoma. Med Sci Monit 20: 1255-1262, 2014.

18. Michl P, Barth C, Buchholz M, Lerch MM, Rolke M, Holzmann KH, Menke A, Fensterer H, Giehl K, Löhr M, et al: Claudin-4 expression decreases invasiveness and metastatic potential of pancreatic cancer. Cancer Res 63: 6265-6271, 2003.

19. Rangel LB, Agarwal R, D'Souza T, Pizer ES, Alò PL, Lancaster WD, Gregoire L, Schwartz DR, Cho KR and Morin PJ: Tight junction proteins claudin-3 and claudin- 4 are frequently overexpressed in ovarian cancer but not in ovarian cystadenomas. Clin Cancer Res 9: 2567-2575, 2003.

20. Jun KH, Kim JH, Jung JH, Choi HJ and Chin HM: Expression of claudin-7 and loss of claudin-18 correlate with poor prognosis in gastric cancer. Int J Surg 12: 156-162, 2014.

21. Brokalaki EI, Weber F, Sotiropoulos GC, Daoudaki M, Cicinnati VR and Beckebaum S: Claudin-7 expression in hepatocellular carcinoma. Transplant Proc 44: 2737-2740, 2012.

22. Singh AB, Sharma A and Dhawan P: Claudin family of proteins and cancer: An overview. J Oncol 2010: 541957, 2010.

23. Resnick MB, Konkin T, Routhier J, Sabo E and Pricolo VE: Claudin-1 is a strong prognostic indicator in stage II colonic cancer: A tissue microarray study. Mod Pathol 18: 511-518, 2005.

24. Ersoz S, Mungan S, Cobanoglu U, Turgutalp H and Ozoran Y: Prognostic importance of claudin-1 and claudin-4 expression in colon carcinomas. Pathol Res Pract 207: 285-289, 2011.

25. Usami Y, Chiba H, Nakayama F, Ueda J, Matsuda Y, Sawada N, Komori T, Ito A and Yokozaki H: Reduced expression of claudin-7 correlates with invasion and metastasis in squamous cell carcinoma of the esophagus. Hum Pathol 37: 569-577, 2006.

26. Al Moustafa AE, Alaoui-Jamali MA, Batist G, Hernandez-Perez M, Serruya C, Alpert L, Black MJ, Sladek R and Foulkes WD: Identification of genes associated with head and neck carcinogenesis by cDNA microarray comparison between matched primary normal epithelial and squamous carcinoma cells. Oncogene 21: 2634-2640, 2002.

27. Kominsky SL, Argani P, Korz D, Evron E, Raman V, Garrett E, Rein A, Sauter G, Kallioniemi OP and Sukumar S: Loss of the tight junction protein claudin-7 correlates with histological grade in both ductal carcinoma in situ and invasive ductal carcinoma of the breast. Oncogene 22: 2021-2033, 2003.

28. Tokés AM, Kulka J, Paku S, Máthé M, Páska C, Lódi C, Kiss A and Schaff Z: The expression of five different claudins in invasive breast carcinomas: Comparison of pT1pN1 and pT1pN0 tumors. Pathol Res Pract 201: 537-544, 2005.

29. Hsueh C, Chang YS, Tseng NM, Liao CT, Hsueh S, Chang JH, Wu IC and Chang KP: Expression pattern and prognostic significance of claudins 1,4 and 7 in nasopharyngeal carcinoma. Hum Pathol 41: 944-950, 2010.

30. Tassi RA, Bignotti E, Falchetti M, Ravanini M, Calza S, Ravaggi A, Bandiera E, Facchetti F, Pecorelli S and Santin AD: Claudin-7 expression in human epithelial ovarian cancer. Int J Gynecol Cancer 18: 1262-1271, 2008.

31. Rendón-Huerta E, Teresa F, Teresa GM, Xochitl GS, Georgina AF, Veronica ZZ and Montaño LF: Distribution and expression pattern of claudins 6,7 and 9 in diffuse- and intestinal-type gastric adenocarcinomas. J Gastrointest Cancer 41: 52-59, 2010.

32. Nakayama F, Semba S, Usami Y, Chiba H, Sawada N and Yokozaki H: Hypermethylation-modulated downregulation of claudin-7 expression promotes the progression of colorectal carcinoma. Pathobiology 75: 177-185, 2008.

33. Nakagawa S, Miyoshi N, Ishii H, Mimori K, Tanaka F, Sekimoto M, Doki Y and Mori M: Expression of CLDN1 in colorectal cancer: A novel marker for prognosis. Int J Oncol 39: 791-796, 2011. 